\title{
HIGHER-ORDER THINKING SKILLS (HOTS) ANALYSIS OF STUDENTS IN SOLVING HOTS QUESTION IN HIGHER EDUCATION
}

\author{
Siti Rohmi Yuliati \& Ika Lestari \\ Program Studi PGSD, FIP UNJ
}

\author{
Jl. Taman Setia Budi II No.1, RT.2/RW.2, Kuningan, Setia Budi, DKI Jakarta 12910
}

\begin{abstract}
Students of Elementary School Teacher Education programs must be able to have higher-order thinking skills (HOTS) so that they can train students to have HOTS through learning activities created when they have become elementary school teachers. This study aims to explain students' high-level thinking skills in solving HOTS-oriented questions in Instructional Evaluation courses. This study uses qualitative research methods with data collection techniques using cognitive test instruments in the form of descriptions. Data analysis techniques use simple descriptive statistics. The results showed the level of thinking ability of students in answering HOTS practice questions still needed improvement. Students who have high learning abilities are better at answering HOTS-oriented questions compared to students in the medium and low categories. Recommendations for future research are required learning modules that can facilitate learning activities that lead to HOTS so that students are skilled in answering and making HOTS-oriented practice questions for elementary school students when they become a teacher.
\end{abstract}

Keywords: higher-order thinking skills, critical thinking, instructional evaluation, problem solving

\section{ANALISIS HIGHER-ORDER THINKING SKILLS (HOTS) SISWA DI INDONESIA DALAM MEMECAHKAN PERTANYAAN HOTS DI PERGURUAN TINGGI}

\begin{abstract}
Abstrak: Mahasiswa program Pendidikan Guru Sekolah Dasar harus memiliki Higher-Order Thinking Skills (HOTS) sehingga mereka dapat melatih siswa untuk memiliki HOTS melalui kegiatan belajar ketika mereka telah menjadi guru sekolah dasar. Penelitian ini bertujuan untuk menjelaskan kemampuan berpikir tingkat tinggi mahasiswa dalam memecahkan pertanyaan berorientasi HOTS dalam kursus Evaluasi Instruksional. Penelitian ini menggunakan metode penelitian kualitatif dengan teknik pengumpulan data menggunakan instrumen tes kognitif berupa uraian. Teknik analisis data menggunakan statistik deskriptif sederhana. Hasil penelitian menunjukkan tingkat kemampuan berpikir mahasiswa dalam menjawab soal latihan HOTS masih perlu ditingkatkan. Mahasiswa yang memiliki kemampuan belajar tinggi lebih baik dalam menjawab pertanyaan berorientasi HOTS dibandingkan dengan mahasiswa dalam kategori sedang dan rendah. Rekomendasi untuk penelitian masa depan diperlukan modul pembelajaran yang dapat memfasilitasi kegiatan pembelajaran yang mengarah ke HOTS sehingga mahasiswa terampil dalam menjawab dan membuat soal latihan berorientasi HOTS untuk siswa sekolah dasar ketika mereka menjadi guru.
\end{abstract}

Kata-kata kunci: higher-order thinking skills, berpikir kritis, evaluasi instruksional, pemecahan masalah

\section{INTRODUCTION}

For the level of higher education, students not only have low thinking skills (LOT), but also must have high-level thinking skills (HOTS) so that they need to be in every learning activity today (Kusuma, Rosidin, Abdurrahman, \& Suyatna, 2017; Sulaiman, Muniyan, Madhvan, Hasan, \& Rahim, 2017) and become a difficult multidimensional challenge in the field of education (Raiyn \& Tilchin, 2015). Higher-order thinking skills (HOTS) lead to the ability to apply knowledge, skills and values in reasoning, reflection, problem solving, decision making, innovating and creating new things (Kusuma et al., 2017; Sulaiman et al., 2017; Abdullah, Abdul Halim; Mokhtar, Mahani; Halim, Noor Dayana Abd; Ali, Dayana Farzeeha; Tahir, Lokman Mohd; Kohar, 2017; Hugerat \& Kortam, 2014).

The preliminary study conducted on 100 students in January 2018 found that a majority $(80 \%)$ of students answered that they still did not know the whole concept of HOTS; most (95\%) students do not 
have references related to HOTS; a majority (70\%) of students answer lecture assignments given by the lecturers are only paper-based so students only take from internet sources without prior analysis (copy paste from the Internet); and a majority (78\%) students want a learning source for the form of Instructional Evaluation courses that taught about HOTS. Based on the results of the study, it can be seen that HOTS that is owned by students seems to be less than optimal because in their daily routines just like in a lecture just sit, listen, and note. Analysis, evaluation and creation activities are rarely trained in students. During this time, student's easily complete practice questions in Instructional Evaluation courses because the types of exercise questions given only involve memorizing or memorizing formulas, so that when students are given practice questions that require more complex completion tend to feel difficult with the given practice questions. Many studies have been conducted oriented about HOTS, for example, HOTS oriented module development for ESL students (Kaur, Singh, Kaur, Singh, \& Singh, 2018), instructional methods that affect HOTS (Hugerat \& Kortam, 2014; Ersoy \& Başer, 2014; Budsankom, P; Sawangboon, T; Damrongpanit, S; Chuensirimongkol, 2015), the use of technology to train HOTS (Edwards, 2016; Duan, 2012; McLoughlin \& Mynard, 2009; Chinedu, Olabiyi, \& Kamin, 2015), and the level of knowledge and practice of HOTS implementation by teachers (Abdullah, Abdul Halim; Mokhtar, Mahani; Halim, Noor Dayana Abd; Ali, Dayana Farzeeha; Tahir, Lokman Mohd; Kohar, 2017). All the research that has been done has sought to improve HOTS towards students but there is no research that examines the level of ability of prospective teacher students in answering high-level thinking questions so that later they can make HOTS practice questions for their students when actually becoming a teacher. Based on the results of previous research that has been done, this study This study aims to explain students' high-level thinking skills in solving HOTS-oriented questions in Instructional Evaluation courses.

Higher-order thinking skills have a higher level of thinking than memorizing facts or retelling something that is heard. Memorizing facts or retelling included in low-level thinking skills because students are similar to robots who only repeat what is obtained and do what they are told to do so that they do not go through the process of deep thinking (Thomas \& Thorne, 2009). HOTS is more of an act of drawing conclusions, connecting with other facts and concepts, manipulating, categorizing, combining with new ways, and applying them to find new solutions for new problems (Thomas \& Thorne, 2009). HOTS includes the ability to think critically, reflective, meta-cognitive, creative thinking (King, Goodson, \& Rohani, 1998; Nguyen, 2018; Snyder \& Snyder, 2008), decision making, and problem solving (Miri, David, \& Uri, 2007). Therefore, this study takes the cognitive process dimension from the Bloom Taxonomy revision (Anderson and Krathwohl) on analysis, evaluation, and creation.

\section{RESEARCH METHODOLOGY}

This research is included in quantitative research because it uses a test instrument in the form of a description that produces the mastery score of the material. The study was conducted on 9 students who took Instructional Evaluation courses in August December 2017 with a purposefully determined three students with consideration of their high learning abilities, three students having moderate learning abilities, and three students having low learning abilities. Data analysis techniques are quantitative and qualitative. Quantitative data were analyzed using simple descriptive statistics while qualitative data explained the cognitive levels that students had mastered. A description test is made by entering Bloom's taxonomic revision (Anderson and Krathwohl Revision) which consists of analysis, evaluation, and creation. Therefore, four description questions were made covering the three cognitive levels.

The research procedure is carried out by giving a description test that contains HOTS so that the researcher can obtain detailed information. The questions given include analysis, evaluation, and creation. The results of student answers in the description questions are categorized based on their ability to think. The HOTS category is shown in table 1.

Table 1

\begin{tabular}{cc} 
Category Level from HOTS (Kusuma et al., 2017) \\
\hline Student scores & HOTS level \\
\hline $100-76$ & Excellent \\
$75-51$ & Good \\
$50-26$ & Enough \\
$25-1$ & Poor \\
\hline
\end{tabular}

Students are categorized based on the categorization in table 1. After completing the description test, the students' answers are converted into quantitative data to facilitate in determining the HOTS category of students. The results of the 
HOTS category become a foothold in determining students' thinking ability. As for the instrument of the description questions given to students as follows.

Table 2

Open question grid for students

\begin{tabular}{|c|c|c|}
\hline Final Competency & Indicator & Dimensions \\
\hline \multirow[t]{4}{*}{$\begin{array}{l}\text { Make HOTS- } \\
\text { oriented questions } \\
\text { for elementary } \\
\text { school students }\end{array}$} & $\begin{array}{l}\text { Explain the reason } \\
\text { for the evaluation } \\
\text { activity consists of } \\
\text { measurement and } \\
\text { assessment }\end{array}$ & Analysis \\
\hline & $\begin{array}{l}\text { Evaluate the effect } \\
\text { of evaluation on } \\
\text { school quality }\end{array}$ & Evaluation \\
\hline & $\begin{array}{l}\text { Analyze the causes } \\
\text { of evaluation failure } \\
\text { in learning }\end{array}$ & Analysis \\
\hline & $\begin{array}{l}\text { Creating evaluation } \\
\text { questions in } \\
\text { learning }\end{array}$ & Creation \\
\hline
\end{tabular}

\section{RESULTS AND DISCUSSION}

In this study, researchers gave a HOTS-oriented question test. The results of the study are presented by dividing student answers into three categories, namely students who have the ability to learn or the power of thinking high, medium, and low. Students are given a description of the practice questions in answering HOTS-oriented questions that train expressing opinions, making conclusions, and making HOTSoriented questions for elementary school students. The following are examples of instruments asked to students.

TESTS FOR ANALYSIS OF NEEDS

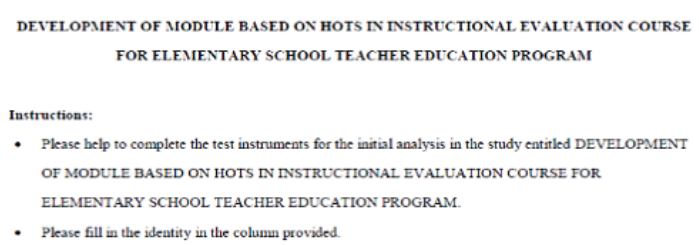

. Plese fir in the ideatity in the columu provided

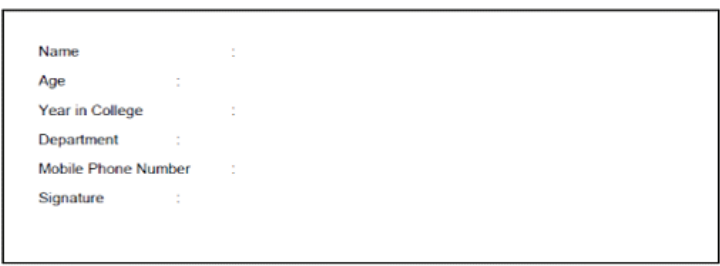

Questions:
1. A good evaluation should consist of measurement and assessment activities, explain why evaluation

activities must involve both of these?
In your opinion, will the evaluation affect the quality of the school. Explain your answert

One of the casies of evaluation failue is that teachers prioritize the achievement of curriculum targets only so that they raxely pay attention to the abily of

4. knowledge about children's aboroption is so important in evaluating!
There are various forms of questions commonly used to evaluate one's abilities. Give examples of

questions from various example
(each one is pust one example)

(each one is just one example)
Complete the choice with four or five options

a Complete the chock

C. Non-objective descriptio

Short answe
Match up

Figure 1. HOTS-oriented question instrument
Questions given to students are presented in Figure 1 . The question type for number 1 is an analysis question, number 2 is an evaluation question, number 3 is an analysis question, and number 4 is a creative question. Students must answer all four questions to know their HOTS. The results are included in the HOTS categorization that has been made in this study. The following is data about student answers when answering questions even though the answers used as examples are only sample answers and not all answers are displayed. But the results of the answer analysis apply to all high, medium, and low student categories. High-ability students (HAS): HAS 1

Based on the results of the description test obtained findings:

Analyze

HAS 1 student can analyze information to answer the questions posed and explain the causal relationship. Evaluate

Students HAS 1 after answering each question asked always to check the answers given.

Create

HAS 1 student can complete practice questions with comprehensive and correct answers except the last question about making HOTS oriented questions for elementary students has not been able to be answered correctly.

From the three aspects, it can be seen if the new HAS 1 student meet two aspects, so they have high-level thinking skills.

HAS 2

Based on the results of the description test obtained findings:

Analyze

Student HAS 2 answers the question by first analyzing the theory needed and then answering the question so that the answer is comprehensive. .

Evaluate

HAS 2 student have assessed all aspects to answer questions comprehensively.

Create

HAS 2 student have not been able to answer for practice questions that make HOTS oriented questions for elementary students. Questions made by HAS 2 student are still memorizing questions.

From the three aspects, it can be seen if HAS 2 student have fulfilled both aspects so that they can be said to have high-level thinking skills.

HAS 3

Based on the results of the description test obtained findings:

Analyze 
HAS 3 student are able to provide deep and comprehensive answers. .

Evaluate

HAS 3 student have assessed all aspects and connected to all aspects comprehensively.

Create

HAS 3 student have not been able to answer for practice questions that make HOTS-oriented questions for elementary students. Questions made by HAS 3 student are still memorized questions.

From the three aspects, it can be seen that HAS 3 student have fulfilled both aspects so that they can be said to have high-level thinking skills. Following are examples of answers given by students in high categories.

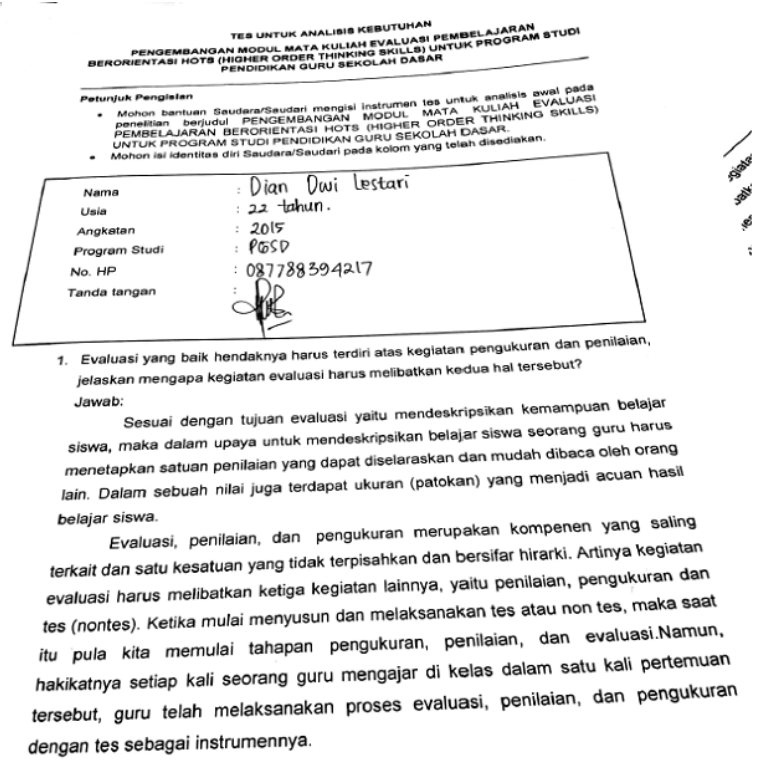

Figure 2. Student answers are high categories

Figure 2. describes the five questions that were asked, the correct answer and in accordance with HOTS came from the students' answers in the high category. which is accompanied by analysis derived from high category student answers. High category students are able to analyze the questions posed so that they answer comprehensively, students first explain the nature or understanding of a concept before analyzing the answers, and at the end of the answers are also given a synthesis of the answers so that one question is able to involve the ability to think analytically and evaluate. However, when students answer question number 4 about making HOTS-oriented questions, they have not been able to make HOTS-oriented questions. Questions made by students only measure students' low-level thinking skills (LOTS). The results of this study are in line with Bakry \& Md Nor Bakar (2015) which states that Junior high-school students with high-level thinking ability can fulfill aspects of analysis, evaluation and creation so that for highly capable students can meet the same three aspects as students who are also skilled in expressing opinions and making conclusions. However, for the ability to create where students make HOTS-oriented practice questions, there are differences in results, students have not been able to make HOTS-oriented practice questions, which are actually required to be mastered by students of Primary School Teacher Education Department.

\section{Moderate-ability students (MAS): MAS 1}

Based on the results of the description test obtained findings:

Analyze

MAS 1 student can relate the theory to the case in question comprehensively.

Evaluate

MAS 1 student was not able to draw conclusions.

Create

MAS 1 student was not able to make HOTS oriented questions for elementary students.

From the three aspects, it can be seen that MAS 2 students have only fulfilled one aspect well, namely to express opinions, while the other two aspects of students have not been able to do it properly so that their thinking ability is still in the moderate level.

\section{MAS 2}

Based on the results of the description test obtained findings:

Analyze

MAS 2 student answer questions by providing comprehensive answers.

Evaluate

MAS 2 student provide conclusions with what is still not true for the analysis made.

Create

MAS 2 student have not been able to answer for practice questions that make HOTS oriented questions for elementary students.

From the three aspects, it can be seen that MAS 2 students have not fulfilled all three aspects, so they are said to have moderate thinking skills.

\section{MAS 3}

Based on the results of the description test obtained findings:

Analyze

MAS 3 student are able to provide deep and comprehensive answers. .

Evaluate

MAS 3 student have not been able to assess all aspects and connect to all aspects comprehensively. 
Create

MAS3 students have not been able to answer for practice questions that make HOTS oriented questions for elementary students.

From the three aspects, it can be seen that MAS 3 students only fulfill one aspect so that they can be said to have moderate thinking skills. Following are examples of answers given by students in the medium category.

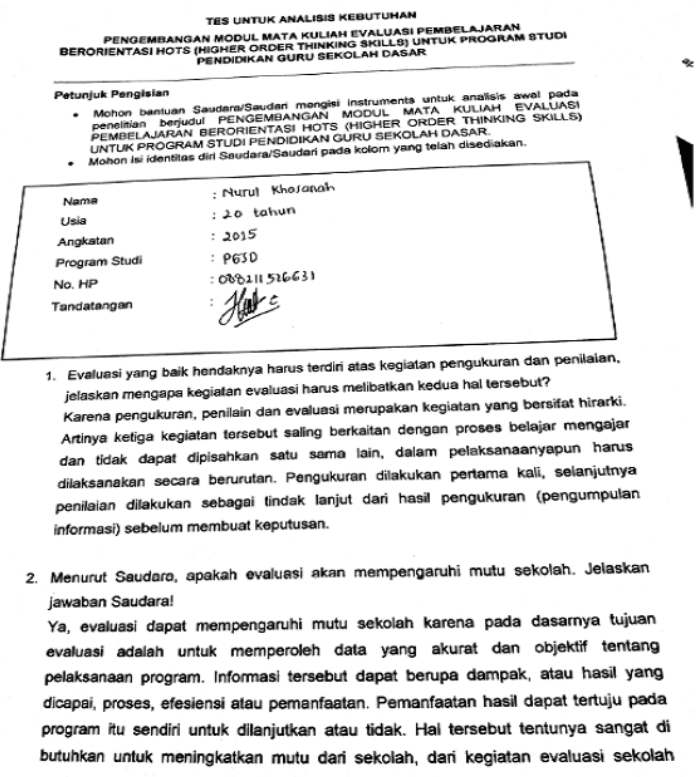

Figure 3. Student answers that are in the medium category

The results of the students' answers are in different categories with high categories. Students who are in the moderate category tend to answer directly to the questions asked so that they are not accompanied by the nature or understanding first. But when answering, the answer has been analyzed but not accompanied by the results of the conclusion or the final answer method. For answers to question number 4 where students are asked to make HOTSoriented questions, they have not been able to make it. Questions made for students, only in the form of training low-level thinking skills (LOTS). Figure 3 contains the answers given by students in the medium category. The results of research by Bakry \& Md Nor Bakar (2015) stated that students who have the power of thinking are able to achieve aspects of creating and expressing opinions but have not been able to conclude. The difference is that the research that has been done is that students are not able to make questions that are HOTS oriented so that they have similarities with students in high categories.

\section{Low-ability students (LAS): LAS 1}

Based on the results of the description test obtained findings:
Analyze

LAS 1 student answer questions briefly.

Evaluate

LAS 1 student have not been able to draw conclusions.

Create

LAS 1 student have not been able to make HOTS oriented questions for elementary students.

From the three aspects, it can be seen if LAS 1 student, their thinking ability is still in a low level.

\section{LAS 2}

Based on the results of the description test obtained findings:

Analyze

LAS 2 student answer questions in brief and unrelated.

Evaluate

LAS 2 student do not provide conclusions at the end of each answer.

Create

LAS 3 student have not been able to answer for practice questions that make HOTS oriented questions for elementary students.

From the three aspects, it can be seen if LAS 2 students are in the category of moderate thinking skills.

\section{LAS 3}

Based on the results of the description test obtained findings:

Analyze

LAS 3 students give incorrect answers.

Evaluate

LAS 3 student give answers that are still incorrect.

Create

LAS 3 student have not been able to answer for practice questions that make HOTS oriented questions for elementary students.

From the three aspects, it can be seen if LAS 3 student are in low-level thinking skills. Following are examples of answers given by students in low categories

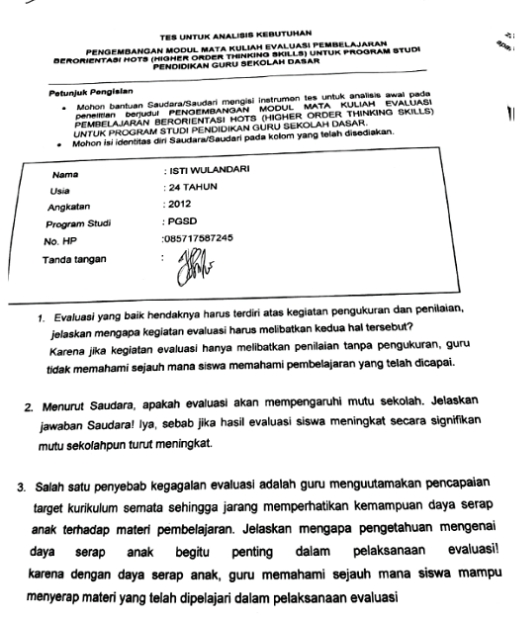

Figure 4. Student answers are low category 
Figure 4 explains about low category students when answering only one sentence is not accompanied by analysis and evaluation. The truth in answering questions is still not right. Students tend to answer directly to the final answer without being accompanied by analysis even though they understand that answering questions should be accompanied by an analysis first. Based on quantitative data, obtained the results of HOTS students:

Table 3

HOTS student assessment results

\begin{tabular}{|c|c|c|c|c|c|c|c|c|c|c|c|}
\hline \multirow{2}{*}{$\begin{array}{c}\text { Final } \\
\text { competence }\end{array}$} & \multirow{2}{*}{ Indicator } & \multirow{2}{*}{$\begin{array}{l}\text { Cognitive } \\
\text { dimension }\end{array}$} & \multicolumn{9}{|c|}{$\begin{array}{l}\text { Student } \\
\text { Score }\end{array}$} \\
\hline & & & 1 & 2 & 3 & 4 & 5 & 6 & 7 & 8 & 9 \\
\hline \multirow[t]{4}{*}{$\begin{array}{l}\text { Make HOTS- } \\
\text { or i e n t e d } \\
\text { ques-tions for } \\
\text { ele-mentary } \\
\text { s c } \mathrm{h} \text { o o o } 1 \\
\text { students }\end{array}$} & $\begin{array}{l}\text { Explain the } \\
\text { reason for the } \\
\text { evaluation } \\
\text { act iv i t } \\
\text { consists of } \\
\text { measurement } \\
\text { and assessment }\end{array}$ & Analysis & 25 & 25 & 25 & 20 & 20 & 25 & 15 & 10 & 15 \\
\hline & $\begin{array}{l}\text { E v a } 1 \text { u a te } \\
\text { the effect of } \\
\text { evaluation on } \\
\text { school quality }\end{array}$ & Evaluation & 20 & 25 & 25 & 20 & 15 & 15 & 15 & 15 & 10 \\
\hline & $\begin{array}{l}\text { Analyze the } \\
\text { causes of } \\
\text { evaluation } \\
\text { failure in } \\
\text { learning }\end{array}$ & Analysis & 25 & 25 & 20 & 20 & 15 & 10 & 15 & 15 & 15 \\
\hline & $\begin{array}{l}\text { Creat ing } \\
\text { evaluation } \\
\text { questions in } \\
\text { learning }\end{array}$ & Creation & 15 & 10 & 15 & 15 & 10 & 10 & 10 & 10 & 10 \\
\hline Final score & & & 85 & 85 & 85 & 75 & 60 & 60 & 55 & 50 & 50 \\
\hline
\end{tabular}

Table 3 explains that as many as three students $(33.33 \%)$ have HOTS in the Excellent category; four students $(44.44 \%)$ are in the Good category; two students $(22.22 \%)$ were in the Enough category. When viewed from this result, students actually showed good HOTS, but if examined based on the results of the cognitive dimension for creative aspects, all students showed weaknesses. Students are still not able to make questions that are HOTS oriented so that they still need a lot of practice.

The five questions given to include analysis, evaluation, and creation and are open descriptions. The results showed that students had not shown good performance in answering HOTS-oriented questions. The reason for this is because answering questions are not carried out comprehensively and clearly, answering such a multiple-choice question model with limited answers. This indicates that the students' content knowledge of the Instructional Evaluation course is still low, especially in their ability to solve HOTS oriented questions. An open description test is deliberately given with consideration of research recommendations (Watson, Collis, Callingham, \& Moritz, 1995) which presents open questions to measure students' thinking abilities followed by a scoring system. Didis, Erbas, Cetinkaya, Cakiroglu,
\& Alacaci (2016) also show that there are still many teachers who only assess students' thinking skills based on the final results (only giving an assessment: right or wrong, good or bad, appropriate or inappropriate). Meanwhile, only a few teachers judge by observing the settlement process.

Often students answer multiple-choice questions that are at the stage of memorizing facts making them patterned in limited thinking. Far different from the abilities demanded by HOTS who oblige to think creatively and critically. Not only students who were low in answering HOTS-oriented questions, the teacher also showed a low level of thinking ability among elementary and secondary school teachers in one province in Malaysia, namely research conducted by (Zulkpli, Mohamed, \& Abdullah, 2017) showing elementary school teachers better prepared in terms of knowledge, skills and attitudes toward the field of pedagogy but weak in thinking skills than secondary school teachers. This condition will later affect the learning achievement of students who are taught (Altun \& Akkaya, 2014; Didis, Erbas, Cetinkaya, Cakiroglu, \& Alacaci, 2016; Stahnke, Schueler, \& Roesken-Winter, 2016). Inconsistencies also occur that the teacher teaches students to complete the steps in problem solving clearly and completely but when given HOTS oriented questions to the teacher, most of the teachers only write the final results and do not include the completion process (Retnawati, Djidu, Kartianom, Apino, \& Anazifa, 2018). This is also the case for this study, where students understand that answering questions should be clear and complete but when given a question only write the final results without an analysis process first. Research by Thompson (2008) examines the teacher's point of view. This study concludes that the mathematics subject teacher has difficulty in interpreting thinking skills in Bloom's taxonomy and creates an assessment instrument in the form of tests for high-level thinking. This can also occur for this study when students were assigned to make HOTS-oriented questions unable to do well for students in the high, medium, and low categories.

Previous findings containing HOTS have occurred in the classroom; teachers rarely try to improve HOTS students' abilities. This can happen because teachers are more interested in mastering the material (Tan \& Halili, 2015). (Tan \& Halili, 2015) added that there are two views, namely (1) teachers think that thinking ability cannot be taught because it is included in the instructor's sense that generally "makes sense" that is done naturally by one's social 
and cultural values. This was supported by Piaget, who explained that the development process was a biological and ineffective process. However, opposed by (Puchta, 2007) which emphasizes that thinking is a natural function, needs to be developed. This opinion is reinforced by Marzano, (1993) which explains if thinking skills need training and can be developed, but cannot be carried out automatically (Nagappan, 2001), both opinions agreed if thinking skills can be taught. The ability to think is a natural thing that is obtained when born and has limited intelligence capacity in each individual so that it is not known exactly the limits of individual thinking abilities. Researchers (Nagappan, 2001; Zohar, 2013; \& Zohar \& Schwartzer, 2005) recommend two approaches, namely infusion approaches referring to HOTS included in specific material learning, and separate-subject approaches that consider HOTS as a general strategy for use in all subjects so that the teacher teaches HOTS as a skill or strategy that will be obtained.

\section{CONCLUSION}

Based on the results from the study, it can be concluded that students still do not have good awareness or understanding in answering HOTSoriented questions. The answers provided are always in the form of a single answer that is not preceded by analysis so that the questions on the form of cognitive analysis processes are not answered by analysis. Even though, students know that answering an analysis question should not be a short answer. Unusualness in answering the description question becomes the biggest obstacle in training HOTS. The recommendations given for further research are that the teacher can begin to provide learning material that supports HOTS skilled students, avoiding multiplechoice tests, even if accompanied by previous case examples. Get used to working on the description test type.

\section{REFERENCES}

Abdullah, Abdul Halim; Mokhtar, Mahani; Halim, Noor Dayana Abd; Ali, Dayana Farzeeha; Tahir, Lokman Mohd; Kohar, U. H. A. (2017). Mathematics Teachers' Level of Knowledge and Practice on the Implementation of Higher-Order Thinking Skills (HOTS). EURASIA Journal of Mathematics, Science and Technology Education, 13(1), 3-17. https:// doi.org/10.12973/eurasia.2017.00601a
Altun, M., \& Akkaya, R. (2014). Mathematics teachers' comments on PISA math questions and our country's students' low achievement levels. Hacettepe Üniversitesi Eğitim Fakültesi Dergisi, 29(1), 19-34.

Bakry, \& Md Nor Bakar. (2015). The process of thinking among Junior High School students in solving HOTS question. International Journal of Evaluation and Research in Education (IJERE), 4(3), 138-145.

Budsankom, P; Sawangboon, T; Damrongpanit, S; Chuensirimongkol, J. (2015). Factors affecting higher order thinking skills of students: A meta-analytic structural equation modeling study. Educational Research and Review, 10(19), 2639-2652. doi:10.5897/err2015.2371

Chinedu, C. C., Olabiyi, O. S., \& Kamin, Y. Bin. (2015). Strategies for improving higher order thinking skills in teaching and learning of design and technology education. Journal of Technical Education and Training, 7(2), 35-43. Retrieved from http://penerbit.uthm.edu.my/ojs/index.php/ JTET/article/view/1081/795

Didis, M. G., Erbas, A. K., Cetinkaya, B., Cakiroglu, E., \& Alacaci, C. (2016). Exploring prospective secondary mathematics teachers' interpretation of student thinking through analysing students' work in modelling. Mathematics Education Research Journal, 28(3), 349-378. https://doi. org/10.1007/s13394-016-0170-6

Duan, J. (2012). Research about Technology Enhanced Higher-Order Thinking. IEEE Computer Society, (Iccse), 687-689. https://doi.org/10.1109/ ICCSE.2012.6295167

Edwards, L. (2016). EDUCATION, TECHNOLOGY AND HIGHER ORDER THINKING SKILLS Lucy Edwards, 1-18.

Ersoy, E., \& Başer, N. (2014). The Effects of Problem-based Learning Method in Higher Education on Creative Thinking. Procedia - Social and Behavioral Sciences, 116, 3494-3498. https:/ / doi. org/10.1016/j.sbspro.2014.01.790

Hugerat, M., \& Kortam, N. (2014). Improving higher order thinking skills among freshmen by teaching science through inquiry. Eurasia Journal of Mathematics, Science and Technology Education, 10(5), 447-454. https://doi.org/10.12973/eurasia.2014.1107a

Kaur, C., Singh, S., Kaur, R., Singh, A., \& Singh, T. S. M. (2018). Developing a Higher Order Thinking Skills Module for Weak ESL Learners, 11(7), 86-100. https://doi.org/10.5539/elt.v11n7p86 
King, F. J., Goodson, L., \& Rohani, F. (1998). Higher Order Thinking Skills. Publication of the Educational Services Program, Now Known as the Center for Advancement of Learning and Assessment. Obtido de: Www.Cala.Fsu.Edu, 1-176. Retrieved from http://www.cala.fsu.edu/files/higher_order_thinking_skills.pdf

Kusuma, M. D., Rosidin, U., Abdurrahman, A., \& Suyatna, A. (2017). The Development of Higher Order Thinking Skill (Hots) Instrument Assessment In Physics Study. IOSR Journal of Research $\&$ Method in Education (IOSRJRME), 07(01), 2632. https://doi.org/10.9790/7388-0701052632

Marzano, R. J. (1993). How classroom teachers approach the teaching of thinking. Theory Into Practice, 32(3), 154-160. https://doi. org/10.1080/00405849309543591

McLoughlin, D., \& Mynard, J. (2009). An analysis of higher order thinking in online discussions. Innovations in Education and Teaching International, 46(2), 147-160. https://doi. org/10.1080/14703290902843778

Miri, B., David, B. C., \& Uri, Z. (2007). Purposely teaching for the promotion of higher-order thinking skills: A case of critical thinking. Research in Science Education, 37(4), 353-369. https://doi. org/10.1007/s11165-006-9029-2

Nagappan, R. (2001). Language teaching and the enhancement of higher-order thinking skills. Anthology Series-Seameo Regional Language Centre, (April 2000), 190-223. Retrieved from http:// nsrajendran.tripod.com/Papers/RELC2000A. pdf

Nguyen, T. (2018). Teachers ' Capacity of Instruction for Developing Higher - Order Thinking Skills for Upper Secondary Students - A Case Study in Teaching Mathematics in Vietnam, 10(1), 8-19.

Puchta, H. (2007). More than little parrots: Developing young learners' speaking skills. Www.Herbertpuchta.Com.

Raiyn, J., \& Tilchin, O. (2015). Higher-Order Thinking Development through Adaptive Problem-based Learning. Journal of Education and Training Studies, 3(4), 93-100. https:// doi.org/10.11114/jets. v3i4.769

Retnawati, H., Djidu, H., Kartianom, K., Apino, E., \& Anazifa, R. D. (2018). Teachers' knowledge about higher-order thinking skills and its learning strategy. Problem of Education in the 21st Century, 76(2), 215-230. Retrieved from http:/ / oaji.net/articles/2017/457-1524597598.pdf

Snyder, L. G., \& Snyder, M. J. (2008). Teaching critical thinking and problem solving skills. The Delta Pi Epsilon Journal, L(2), 90-99. https:// doi. org/10.1023/A:1009682924511

Stahnke, R., Schueler, S., \& Roesken-Winter, B. (2016). Teachers' perception, interpretation, and decision-making: a systematic review of empirical mathematics education research. ZDM - Mathematics Education, 48(1-2). https://doi. org/10.1007/s11858-016-0775-y

Sulaiman, T., Muniyan, V., Madhvan, D., Hasan, R., \& Rahim, S. S. A. (2017). Implementation of higher order thinking skills in teaching of science: A case study in Malaysia. International Research Journal of Education and Sciences (IRJES), 1(1), 2550-2158. Retrieved from http://www.masree. info/wp-content/uploads/2017/02/20170226IRJES-VOL-1-ISSUE-1-ARTICLE-1.pdf

Tan, S. Y., \& Halili, S. H. (2015). Effective teaching of higher-order thinking (HOT) in education. The Online Journal of Distance Education and E-Learning, 3(2), 41-47.

Thomas, A., \& Thorne, G. (2009). How to increase higher level thinking | center for development and learning. The Center for Learning and Development Blog. Retrieved from http:/ / www.cdl.org/ articles/how-to-increase-high-order-thinking/ Thompson, T. (2008). Mathematics teachers' interpretation of higher-order thinking in Bloom's taxonomy. International Electronic Journal of Mathematics Education, 3(2), 96-109. https:// doi. org/10.1126/science.318.5856.1534

Watson, J. M., Collis, K. F., Callingham, R. A., \& Moritz, J. B. (1995). A model for assessing higher order thinking in statistics. Educational Research and Evaluation, 1. https://doi. org/10.1080/1380361950010303

Zohar, A. (2013). Challenges in wide scale implementation efforts to foster higher order thinking (HOT) in science education across a whole school system. Thinking Skills and Creativity, 10, 233-249. https:// doi.org/10.1016/j. tsc.2013.06.002

Zohar, A., \& Schwartzer, N. (2005). Assessing teachers' pedagogical knowledge in the context of teaching higher-order thinking. International Journal of Science Education, 27(13), 1595-1620. https:/ / doi.org/10.1080/09500690500186592

Zulkpli, Z., Mohamed, M., \& Abdullah, A. H. (2017). Assessing mathematics teachers' knowledge in teaching thinking skills. Sains Humanika, 9(1-4), 83-87. https://doi.org/10.11113/ sh.v9n1-4.1129 